\title{
Genital and sperm characteristics of wild, free rangingred deer stags (Cervus elaphus $L$ ) hunted in different regions of Poland
}

\author{
Z Gizejewski, L Söderquist and Heriberto Rodriguez-Martinez
}

\section{Linköping University Post Print}

\section{Tweet}

N.B.: When citing this work, cite the original article.

Original Publication:

Z Gizejewski, L Söderquist and Heriberto Rodriguez-Martinez, Genital and sperm characteristics of wild, free rangingred deer stags (Cervus elaphus L) hunted in different regions of Poland, 2010, Widlife Biology in Practice, (6), 2, 81-94.

http://dx.doi.org/10.2461/wbp.2010.6.7

Copyright: The authors. Under Creative Commons Licenses http://socpvs.org/

Postprint available at: Linköping University Electronic Press

http://urn.kb.se/resolve?urn=urn:nbn:se:liu:diva-65487 


\section{ORIGINAL PAPER}

GENITAL AND SPERM CHARACTERISTICS OF WILD, FREE RANGING RED DEER STAGS (CERVUS elaphus L) hunted in different Regions of Poland

\section{Z. Gizejewski1 ${ }^{1,2}$, L. Söderquist ${ }^{2} \&$ H. Rodriguez-Martinez ${ }^{3, *}$}

1 Institute of Animal Breeding and Food Research, Polish Academy of Sciences, PL-10-747 Olsztyn, Poland.

2 Department of Clinical Sciences, Faculty of Veterinary Medicine and Animal Sciences, SLU, S-750 07 Uppsala, Sweden.

3,* Corresponding author: Department of Clinical and Experimental Medicine, Faculty of Health Sciences, Campus HU/US, Developmental biology, Lab1, floor 12, Linköping University, SE-581 85 Linköping, Sweden.

Tel: +46-(0)10-1032284; Fax: +46 (0)101034789; E-mail: heriberto.rodriguez-martinez@liu.se

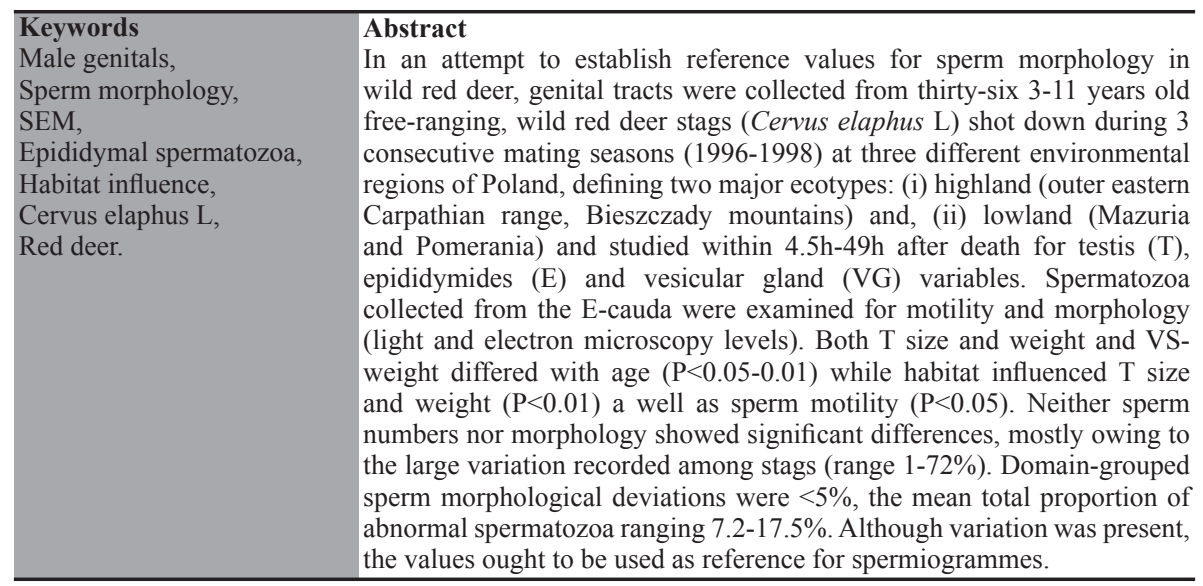

\section{Introduction}

Of the about 40 existing deer species and about 200 subspecies, nearly half have been classified as vulnerable or endangered by the International Union for Conservation of Nature, IUCN [1]. At present, nine subspecies of red deer (Cervus elaphus L) are differentially considered, three as endangered, one as vulnerable, one as nearly threatened and four without enough data to give a category ("Data Deficient"). The species as a whole, however, is listed as of least concern. However, this was based on the traditional classification of red deer as one species (Cervus elaphus L), including the North American wapiti (Elk), by IUCN [1]. Reproductive data from wild red deer stags/harts, despite their status of as least concern and of an increasing population trend [1], are however scarce for some habitats and populations. This is not surprising, since most available data are retrieved from captive specimens, with important studies starting by the early 1990's on basic reproduction [2] and soon reaching biotechnological levels by use of in vitro embryo production [2] and culminating with the cloning of red deer in New Zealand by Berg et al. [3]. However, despite the plethora of information gathered this far in captive or farmed populations, such information should have made complementary to that of wild cohorts [4]. Few wild red deer stags have been examined post-mortem in Western Europe (Cervus elaphus elaphus) or Eastern Europe (Cervus elaphus hippelaphus), despite 
efforts made already from the early 1970's [5]. Moreover, there is yet uncertainty regarding the taxonomy of the European red deer, were Eastern European red deer is named Cervus elaphus maral in contrast to the Western European ones (Cervus elaphus elaphus) [6]. Most European studies have been done in Spain (Cervus elaphus hispanicus), reviewed by Garde et al. [7], why basic reproductive data in other subspecies or varieties such as Cervus elaphus maral are yet missing, including sperm production, morphology and viability. The latter is of paramount importance when semen is stored for gene banking [8] or when artificial reproduction techniques are attempted in endangered deer species and subspecies [7]. The establishment of methods for semen preservation for artificial insemination (AI) should be preceded by evaluation of the morphological and physiological parameters [7].

Semen collection from different wild cervids is possible by electroejaculation under general anaesthesia [9-14] and spermatozoa can be processed for AI using refrigeration $[15,16]$ or even cryopreservation [17-23]. Various methods of semen collection using an artificial vagina have been developed, making possible semen collection from fenced, quasi tamed animals [24-26]. Spermatozoa can also be collected post-mortem from the caudae epididymides [27,28] thus enabling the evaluation and further processing of spermatozoa from valuable wild red deer stags occasionally shot down during the reproductive season [29,30]. However, well-performed evaluations of sperm production, sperm quality and the activity of the accessory sex glands are scarce, particularly related to wild populations, and their habitats [14].

The aims of the present study were, therefore, to determine if genital and sperm characteristics of wild, free-ranging red deer stags hunted during three consecutive breeding seasons varied between three different environmental regions of Poland, defining two major ecotypes: (i) highland (outer eastern Carpaths, Bieszczady mountains) and, (ii) lowland (Mazuria and Pomerania). Ultimately, the study attempts to establish reference values for sperm morphology in this species.

\section{Material and Methods}

\section{Animals}

Male genital organs were collected during the mating season (September) during three consecutive years (1996-1998) from 36 free-ranging wild red deer stags in three different geographical areas of Poland (see Fig. 1), which determined two major habitats: highland, in the outer eastern Carphatian Bieszczady mountains $(C$, $>1,000 \mathrm{~m}$ above sea level, with $>950 \mathrm{~mm}$ of average rainfall per vegetation period typically continental highland area) and, lowland in Mazuria (M) and Pomerania (P, Pomorze) ( $\sim 100 \mathrm{~m}$ above sea level and $\sim 400$ of average annual rainfall at the Baltic sea influence) with major flora differences [31]. The number of stags collected per area was 12 . The ambient temperature at the time of sampling ranged between 8 and $14^{\circ} \mathrm{C}$. The age of the stags was estimated according to their dental status [32] and varied between 3 to 11 years old $(8.8 \pm 2.1 ; 8.0 \pm 2.3$ and $6.1 \pm 1.5$ years, respectively, means $\pm \mathrm{SD}$ ). The mean carcass weight (mean clean weight without head) was $146 \mathrm{~kg}$ (range: $80-182 \mathrm{~kg}$ ). The male genital organs were retrieved within 4.5-49 hours (mean approx. $15 \mathrm{~h}$ ) after the stags were shot, and kept refrigerated during transportation to the laboratory. 


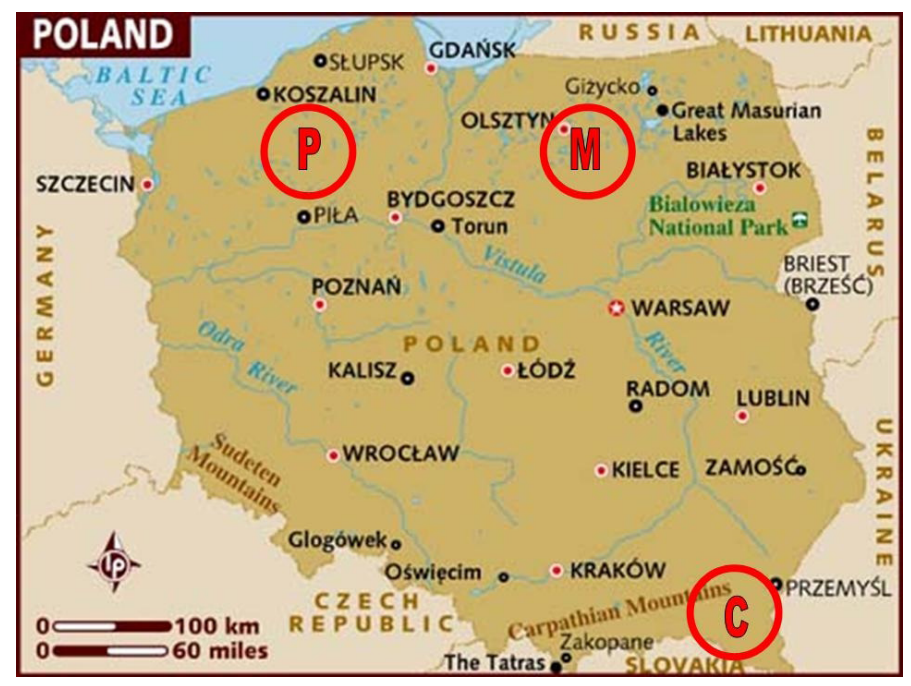

Fig. 1. Areas of hunting of the wild, free ranging red deer stags, marking three different geographical areas of Poland and which determined two major habitats: highland, in the eastern Carphatian Bieszczady mountains (C) and, lowland in Mazuria (M) and Pomerania (Pomorze, P) (http://www.lonelyplanet.com/ maps/europe/poland/map_of_poland.jpg).

\section{Data collection}

Both testes/epididymides and vesicular glands (VG) were weighed on the electronic balance WGILAB, Poland (resolution: 0.01g) and measured using an electronic calliper. Fluid was collected from the caudae epididymides (CE) into graduated Eppendorf test tubes, after multiple incisions by gently squeezing of the $\mathrm{CE}$, and the volume was assessed. A similar procedure was used to collect and measure the volume of the fluid from the vesicular glands.

\section{Evaluation of the epididymal spermatozoa}

The CE fluid was extended immediately after sampling with physiological saline (buffered with calcium chloride and magnesium chloride) and sperm motility was thereafter estimated under a light microscope equipped with phase contrast optics (BIOLAR PZO, Warszawa, Poland, x 125) and a heated block $\left(+38^{\circ} \mathrm{C}\right)$ for samples collected in Mazuria and Pomerania, but not in the Carpathian area. The sperm concentration was later assessed in a Bürker chamber

\section{Sperm morphology}

Drops of the extended CE-fluid were fixed with buffered formaldehyde solution for sperm morphological examination [33]. Two hundred spermatozoa each in wet smears were counted using light microscope equipped with a phase contrast optics with an immersion objective lens at 1,000x magnification. Spermatozoa displaying morphological abnormalities, including proximal and distal cytoplasmic droplets, loose heads, acrosome defects and abnormalities, nuclear pouches, abnormal midpieces and tail defects, were identified. CE-spermatozoa were also evaluated in air- 
dried smears stained with Williams solution (carbol-fuchsin-eosin), as described by Williams [34] and modified by Lagerlöf [35]. Five hundred spermatozoa were examined in a light microscope at $1,000 \mathrm{x}$ magnification in these slides, to count sperm head shape abnormalities (pear shape, narrowness at the base, abnormal contour, undeveloped, narrowness, abaxial implantation and abnormal loose heads). The sperm abnormalities were recorded as a percentage of the total number of the counted spermatozoa.

\section{Scanning electron microscope (SEM)}

Hancock's fixed spermatozoa $(0.2 \mathrm{~mL})$ were further processed for SEM, by transferring these to a syringe and the contents passed through a Nucleopore filter chamber ( $2 \mu \mathrm{m}$ pore size; SPI-Pore Filter Structure Probe, West Chester, PA, USA) in order to deposit the spermatozoa onto a solid base. The filter chamber was rinsed twice with cacodylate buffer and then post-fixed in a $2 \%$ solution of osmium tetroxide in phosphate buffered saline (PBS) for 2 hours. The spermatozoa were then dehydrated by exposure to an increasing graded concentration of alcohol $(30,50,70,95$, and $100 \%$ alcohol), after which the filter chamber was opened and the filter transferred into a beaker with 100\% acetone. A hexamethyldisilazane (HMDS) and acetone mixture was thereafter used, first in a 1:25 proportion (1h), then in a 1:1 proportion (2h), and finally 100\% HMDS until the next day when the sample was dry. The filter was mounted on SEM stubs and coated with platinum/palladium in a Cressington sputter (Agar High Resolution Sputter Coater; Agar Scientific Ltd. Stansted, Essex, England). Analyses of the samples were performed in a JEOL Scanning Microscope $6320 \mathrm{~F}$ (Tokyo, Japan) at $5 \mathrm{KV}$, and the digital images were collected using the program Semafore (JEOL).

\section{Statistical analyses}

Data regarding T, E and VG size/weight, VS- and CE-fluid content, sperm concentration ( $\log$ transformed), motility and proportions of sperm abnormalities (square-root transformed) were stratified into collection area-habitat and age classes and analyzed using the general linear model (GLM) procedure of the Statistical Analysis System (SAS) software, version 8 (SAS Institute, Cary, NC, USA, 2004). Differences were declared significant at $\mathrm{P}<0.05$.

\section{Results}

Taking the entire 36 stags as a population, testis size varied among the stags, with a mean length of $8.6 \mathrm{~cm}( \pm 0.9 \mathrm{~cm}, \mathrm{SD})$. Considerable variation was also found in testis weight, which ranged between 20 and $260 \mathrm{~g}$ (mean $\pm \mathrm{SD}, 129.5 \pm 40 \mathrm{~g}$ ). In one of the stags ( $\mathrm{nr} 7$ ) the testes were considerably unequal in size, the right testis being remarkably small (weight $20 \mathrm{~g}$ ), while the left testis was significantly larger and heavier (260 g). The mean ( \pm SD and range) age, carcass weight and weight of testes $(\mathrm{R}+\mathrm{L})$ and vesicular glands $(\mathrm{VG})$ of wild European red deer stags (Cervus elaphus L) hunted in three geographical habitats of Poland (Mazuria, Pomerania and the eastern Carphatian Bieszczady mountains) are presented in Table 1. Although there 
is a tendency for the stags hunted in the mountain area to be older and thus to have heavier organs, such differences between areas were masked by the large individual variation registered. The VG contained a yellowish fluid, that resembled fresh honey as per consistency, density and colour, and whose volume (paired VGs) varied significantly among the sampled stags (mean 17.0 \pm 11.9 , range 3.0-49.0 mL).

Table 1. Age, carcass weight and weight of testes $(\mathrm{R}+\mathrm{L})$ vesicular glands $(\mathrm{VG})$ in free ranging wild European red deer stags (Cervus elaphus L) $(n=36)$ hunted in three habitats of Poland (Mazuria, Pomerania and the eastern Carphatian Bieszczady mountains), mean \pm SD and range, in parenthesis).

\begin{tabular}{|c|c|c|c|}
\hline \multirow[b]{2}{*}{ Parameter } & \multicolumn{3}{|c|}{ Habitat / area of hunting } \\
\hline & $\begin{array}{l}\text { Mazuria } \\
\mathrm{n}=12\end{array}$ & $\begin{array}{l}\text { Pomerania } \\
\mathrm{n}=12\end{array}$ & $\begin{array}{l}\text { Carpaths (Bieszczady m) } \\
\mathrm{n}=12\end{array}$ \\
\hline Estimated age (years) & $\begin{array}{l}8.0 \pm 2.3 \\
(3-10)\end{array}$ & $\begin{array}{l}6.1 \pm 1.5 \\
(3-8)\end{array}$ & $\begin{array}{l}8.8 \pm 2.1 \\
(3-11)\end{array}$ \\
\hline Carcass weight (kg) & $\begin{array}{l}134.8 \pm 16.9 \\
(92-155)\end{array}$ & $\begin{array}{l}114.8 \pm 21.4 \\
(80-140)\end{array}$ & $\begin{array}{l}145.9 \pm 26.2 \\
(80-182)\end{array}$ \\
\hline Right testis (g) & $\begin{array}{l}112.7 \pm 31.9 \\
(34-152)\end{array}$ & $\begin{array}{l}117.1 \pm 36.9 \\
(65-165)\end{array}$ & $\begin{array}{l}142.1 \pm 48.6 \\
(20-195)\end{array}$ \\
\hline Left testis $(\mathrm{g})$ & $\begin{array}{l}122.3 \pm 23.2 \\
(80-160)\end{array}$ & $\begin{array}{l}112.9 \pm 32.3 \\
(70-160)\end{array}$ & $\begin{array}{l}169.7 \pm 38.7 \\
(93-260)\end{array}$ \\
\hline VG weight (g) & $\begin{array}{l}54.0 \pm 18.5 \\
(21-81)\end{array}$ & $\begin{array}{l}46.6 \pm 13.2 \\
(20-60)\end{array}$ & $\begin{array}{l}48.6 \pm 8.8 \\
(40-62)\end{array}$ \\
\hline
\end{tabular}

Considering all stags, the fluid of their cauda epididymides (CE) appeared creamywhite and milky in consistency, with a mean total volume of $1.1 \mathrm{~mL}$ (both CE, range 0.2-2.1 mL). The average sperm concentration was $6.1 \times 10^{9}$ spermatozoa $/ \mathrm{mL}$ (range 2.7- $12.7 \times 10^{9} / \mathrm{mL}$ ). The epididymal spermatozoa collected from most CE showed spontaneous motility, except for 5 stags ( $\mathrm{nr} 3,4,10,12,35)$ where no motility could be detected. Table 2 depicts the volume of the cauda epididymides (CE) and the contents (sperm numbers) of spermatozoa and their relative motility (as \% progressive motile spermatozoa) when stags were grouped according to the area/habitat where they were hunted. Once again, the highland (Eastern Carpathian Bieszczady mountains) stags had a relatively higher CE-content, but depicted a lower sperm motility, while sperm numbers was lowest in the Mazurian stags.

Table 2. Volume, total sperm numbers and progressive motility in epididymal caudae (CE) of free ranging wild European red deer stags (Cervus elaphus L) $(n=36)$ hunted in three Polish habitats (Mazuria, Pomerania, eastern Carpathian Bieszczady mountains $)($ mean \pm SD).

\begin{tabular}{llll}
\hline \multirow{2}{*}{ Parameter } & \multicolumn{2}{l}{ Habitat/area of hunting } \\
& $\begin{array}{l}\text { Mazuria } \\
\mathrm{n}=12\end{array}$ & $\begin{array}{l}\text { Pomerania } \\
\mathrm{n}=12\end{array}$ & $\begin{array}{l}\text { Carpaths (Bieszczady m) } \\
\mathrm{n}=12\end{array}$ \\
\hline Volume $(\mathrm{mL})$ & $0.9 \pm 0.4$ & $1.0 \pm 0.5$ & $1.3 \pm 0.4$ \\
Total sperm number $\left(\mathrm{x} 10^{9} / \mathrm{mL}\right)$ & $5.1 \pm 1.6$ & $6.9 \pm 2.5$ & $6.4 \pm 1.6$ \\
Sperm motility $(\%)$ & $43.3 \pm 20.6$ & $52.1 \pm 21.9$ & $20.8 \pm 23.1$ \\
\hline
\end{tabular}

Typical examples of the sperm abnormalities encountered in the CE-spermatozoa from wild European red deer stags, as classified in the present study, are depicted in (using Nomarski differential contrast microscopy) Figures 2a-21. The most common single sperm abnormality was, as expected, the distally placed cytoplasmic droplets, commonly seen in cauda spermatozoa. Besides this "abnormality" proportions of 
abnormal acrosomes were also conspicuous among some stags, while one of the stags (nr 12) presented a specific sperm defect, known as "knobbed-acrosome defect" at an incidence of 50\% (see Figure $2 \mathrm{~g}$ for this defect). Proportions of sperm morphology abnormalities are presented in Table 3 for stags collected in the different hunting areas/habitats. As it can be seen, basically no single domain group (i.e. head, acrosome, mid-piece, tail etc) of sperm abnormalities was above a mean value of $5 \%$. The Pomeranian-hunted stags had the lowest values, compared to Mazurian or Carpathian (Bieszczady mountains) stags. When these values were grouped in totals/area, the mean proportions ranged between 7.2 and 17.5 , i.e. low for ruminants. Variation among stags was, however, very large (1-72\%), with some stags (nr 3, 12 , $13,17,34)$ with much higher incidences of total sperm abnormalities compared to the other stags.
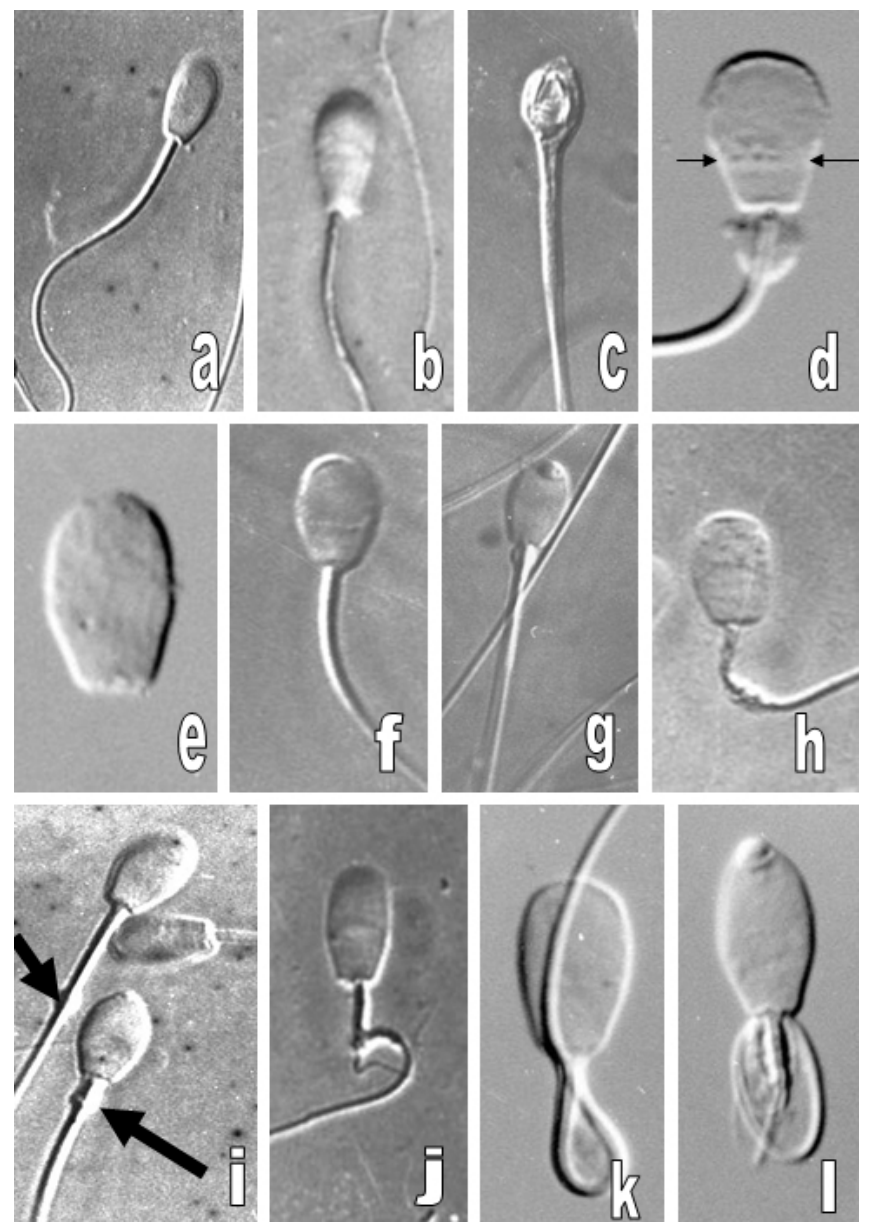

Fig. 2 a-x. Nomarski differential interference contrast (DIC) microscopy of buffered formalin-fixed spermatozoa (wet smears) from wild, free ranging European red deer stags (Cervus elaphus L), depicting the different morphological categories observed in the sperm head, mid-piece, and tail (1,200x). 2a: normal sperm morphology, 2b: pyriform-shaped sperm head, 2c: underdeveloped spermatozoon, 2d: diadem nuclear defect (between arrows), 2e: loose sperm head, 2f: broken acrosome, 2g: knobbed acrosome defect, $2 \mathrm{~h}$ : abaxial tail implantation, 2i: proximal (long arrow) and distal (short arrow) cytoplasmic droplets, $2 \mathrm{j}$ : mid-piece defect, 2k: simple bent tail, 21: tail coiled under the head. 
Table 3. Sperm abnormalities (\%) in epididymal caudae (CE) of wild, free ranging wild European red deer stags (Cervus elaphus L) $(n=36)$ hunted in three Polish areas (Mazuria, Pomerania and the eastern Carpathian Bieszczady mountains)(mean $\pm \mathrm{SD})$.

\begin{tabular}{llll}
\hline \multirow{2}{*}{ Sperm abnormalities } & \multicolumn{2}{l}{ Habitat/area of hunting } \\
& $\begin{array}{l}\text { Mazuria } \\
\mathrm{n}=12\end{array}$ & $\begin{array}{l}\text { Pomerania } \\
\mathrm{n}=12\end{array}$ & $\begin{array}{l}\text { Carpaths (Bieszczady m) } \\
\mathrm{n}=12\end{array}$ \\
\hline Head & $2.7 \pm 1.3$ & $1.8 \pm 1.5$ & $3.9 \pm 3.7$ \\
Acrosomes & $1.3 \pm 1.6$ & $1.4 \pm 3.1$ & $0.8 \pm 0.8$ \\
Proximal cytoplasmic droplet & $4.1 \pm 6.9$ & $1.2 \pm 1.5$ & $3.3 \pm 3.0$ \\
Midpiece & $1.4 \pm 1.1$ & $0.3 \pm 0.4$ & $0.9 \pm 0.7$ \\
Tail & $3.2 \pm 1.9$ & $1.4 \pm 1.6$ & $3.1 \pm 5.5$ \\
Total & $14.6 \pm 9.1$ & $7.2 \pm 5.3$ & $17.5 \pm 19.4$ \\
(range) & $(7.5-41.0)$ & $(1.0-21.0)$ & $(3.9-71.7)$ \\
\hline
\end{tabular}

Micrographs of abnormal spermatozoa are depicted in Figure 3a-h. The SEM fine structure confirmed the morphology seen during the evaluation of wet- or stained smears. The defects were similar to what has been described in other ruminant species, including the presence of crest defects (See Figure $3 \mathrm{c}$ and $3 \mathrm{~h}$ ).

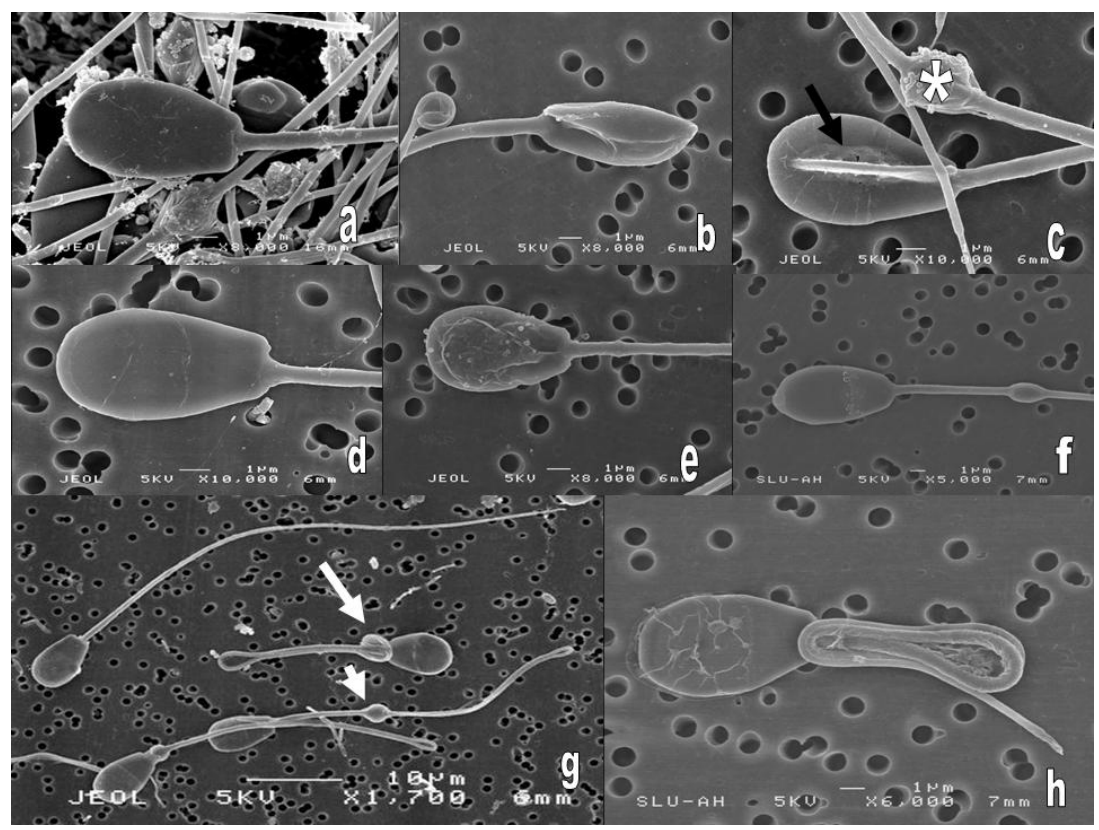

Fig. 3 a-h. Fine structure (scanning electron microscope, SEM) of spermatozoa retrieved from the cauda epdididymides of wild, free ranging European red deer stags (Cervus elaphus L), depicting some different morphological categories observed in the sperm head, mid-piece, and tail. Figure 3a depicts normal morphology, 3b: underdeveloped sperm head, 3c: crest defect (arrow) and a distal cytoplasmic droplet (*), 3d: abaxial tail implantation, 3e: blown up acrosome membrane, $3 \mathrm{f}$ : knobbed acrosome defect, $3 \mathrm{~g}$ : proximal (long arrow) and distal (short arrow) cytoplasmic droplets alongside a spermatozoon with normal morphology, 3 h: sperm tail coiled under the head.

The influence of both hunting area (habitat) and age of the stags on some of the studied variables is summarised in Table 4. Both T size and weight and VG-weight differed with age $(\mathrm{P}<0.05-0.01)$ while habitat influenced $\mathrm{T}$ size and weight $(\mathrm{P}<0.01)$ a well as 
sperm motility $(\mathrm{P}<0.05)$. Neither sperm numbers nor morphology showed significant differences, mostly owing to the large variation recorded among stags (range 1-72\%). Stag $\mathrm{nr} 7$ showing assymetrical testes, was removed from the statistical analysis.

Table 4. Influence of the habitat/area of hunting and age over the studied variables in free ranging, wild European red deer stags (Cervus elaphus L) $(n=36)$ hunted in three Polish areas (M: Mazuria, P: Pomerania, C: eastern Carpathian Bieszczady mountains), T: testis, VG: vesicular gland, CE: cauda epididymides, Spz: spermatozoa.

\begin{tabular}{lcccccc}
\hline & T-size & T-weight & VS-weight & $\begin{array}{c}\text { Sperm numbers } \\
\text { in CE }\end{array}$ & $\begin{array}{c}\text { Sperm } \\
\text { motility }\end{array}$ & $\begin{array}{c}\text { Proportion of abnormal } \\
\text { spermatozoa }\end{array}$ \\
\hline Habitat & $* *$ & $* *$ & $\mathrm{~ns}$ & $\mathrm{~ns}$ & $*$ & $\mathrm{~ns}$ \\
Age & $*$ & $* *$ & $*$ & $\mathrm{~ns}$ & $\mathrm{~ns}$ & $\mathrm{~ns}$ \\
$\begin{array}{l}\text { Significantly different } \\
\text { between areas }\end{array}$ & C-M & C-M & - & & C-M & - \\
\hline
\end{tabular}

$(*: \mathrm{P}<0.05, * *: \mathrm{P}<0.01, * * *: \mathrm{P}<0.001)$

\section{Discussion}

The present study attempted to provide basic anatomic data on selected genitalia of wild, free ranging European red deer stags, hunted down in three geographical areas of Poland, namely Mazuria, Pomerania and the eastern Carpathian Bieszczady mountains, as well as to establish reference values for sperm morphology deviations in the species. Although there is yet controversy about the taxonomy of the Eastern vs Western European stags, perhaps locating the Cervus Elaphus maral among the ones hunted in the eastern Carpathian Bieszczady mountains, the results suggest that other factors, rather than taxonomy play a role. The two first named geographical areas are close to the Baltic Sea and therefore differ both in altitude and rainfall to the Bieszczady mountains, which are placed more than $600 \mathrm{~km}$ south inland in the extreme southeast part of Poland, near the borders of Slovakia and Ukraine. The Bieszczady mountains belong to the outer eastern ridge of the Carpathian range conglomerate with a altitude over 1,000 meters above sea level and a temperate, continental climate, receiving more than double the rainfall compared to the lowland regions. Although the climate between the investigated areas is not dramatically different at first sight, the Mazurian and Pomeranian habitats are closer to the Baltic sea compared to the inland continental eastern Carpaths, and the forest in the Bieszczady mountains benefit from the higher rainfall [31], thus differentiating the flora resources for the free ranging ruminants. Moreover, the regions where the hunting was performed (P, M and $\mathrm{C}$ ) are separated from their surroundings by large rivers such as Vistula river (flowing in direction S-N), Bug river (SE -NW), Warta river (SE-NW) and Notec river (E-W). The red deer stags usually stay in the forest of their own established areas, as it has been the case with other European isolated ecotypes holding subspecies such as Cervus elaphus corsicanus (Corsica), Cervus elaphus scoticus (Scotland and Ireland), Cervus elaphus atlanticus (Norway) or Cervus elaphus hispanicus (Pyrenees).

The present data were basic in terms of being descriptive (weight, size, content volume) of animals hunted for pleasure (or maintenance of a certain population). Hunters seek those males with larger antlers, which defining age and dominance provides, to some extent, an idea of the sexual activity of the male and, possibly, of his fertility. According to the common opinion of the hunters involved in this 
study, the body size of red deer stags from Bieszczady Mountains (eastern Carpaths) is larger compared to the stags from the lowlands, probably a confirmation of the better flora consumed by these animals, in comparison to the forests in the lowland areas. The results of the present study confirm this was the case for the stags sampled during rut in three different years, but they also indicate that there was a certain relationship with age. The size of antlers in both alpha males and of those on top of the hierarchy but not yet alpha males seem to have better semen quality than those with smaller relative size antlers (Gizejewski, unpublished results). However, although the results indicate such a relation, confirming published results [36], the number of stags of the present study is not large enough to reach firm conclusions. On the other hand, a large proportion of stags were younger that the usual hunting suggestion for shooting; beyond 10 years, which indicates that relationships might appear in a larger population sample.

Whether the reproductive parameters differ between wild and captive and between mountain and lowland Cervus elaphus stags still remains to be investigated in a larger male population, but some data recorded and presented in this study appear interesting, albeit anecdotic. In stag $\mathrm{nr} 7$, for instance, the right testis was either hypoplastic or atrophic with a compensatory growth of the contralateral testis, something that occurs in all mammals where an unilateral dysfunction occurs in the gonads [37]. In the same stag, we also noted that the left antler had an abnormal shape. The relevance of this observation is doubtful although the old hypothesis [38] regarding a possible relation between antler asymmetry and testicular pathology tempts into speculation. Such speculation has been newly tested by Spanish researchers [36], where they found that a global measure of relative antler size and its complexity was statistically associated with the relative size of the testes and with sperm velocity as explored with CASA. More importantly, their statistical modelling excluded either body condition or age from being those driving these associations. Very recently, they further established that the larger the testes in wild deer stags during rut, the higher the levels of testosterone. Stags with higher testosterone levels also had improved sperm quality and stronger antlers [39].

Taken together, both testis size and weight and vesicular gland(VG) weight significantly differed with age, and carcass size (as a token of the influence of age, dominance or food availability). There was also a clear influence of habitat (rutting area or hunting area) onto testis size and weight, probably in relation to other phenotypic characters such as antler size and complexity. Macroscopically, the appearance of the fluids obtained from the cauda epididymides (CE, whitish, containing spermatozoa) and that of the vesicular glands (VG, yellowish) looked identical to the two consecutive fractions seen in ejaculates collected with an artificial vagina during mating season from red deer stags [24-26] thus confirming their nature. Compared to the prostate and bulbourethral glands, whose secretion in stags is merely marginal, the size and weight of the VG seems simply follow the relative size of the testes, a non-surprising relationship, since the VG is testosterone-dependent and the larger the size of the testis, the larger the VG. It is not known why neither the prostate nor the bulbourethral glands, being also testosterone-dependent, follow a similar secretion pattern as the VGs. Data of prostatic or bulbourethral secretion were not available for the stags hereby studied.

Besides hormonal production, the testes produce spermatozoa which, following a 
period of sperm maturation while transported through the ducti epididymides, they are stored at the caudae epididymides. Post-mortem, spermatozoa can be found (as they are dislocated by spontaneous contractions of the ducti deferentia and the muscles of the crus penis) in upper segments of the ducti deferentia, the ampullae and even the pelvic urethra [14]. However, we did not have any other possibility than to rely on the volumes and sperm concentrations present in the CE's in order to uniformize the data. In any case, the volume of the whitish fluid obtained from both $\mathrm{CE}$ varied among individuals. Anecdotically, in stag number 12, who appeared to be a dominant male, the content of both caudae epididymides were much lower than average and contained only a few drops (in total approx. $0.2 \mathrm{~mL}$ ). Furthermore, the volume of the yellowish fluid, obtained from both VG, from the same stag was less than one third of the average volume $(14.9 \mathrm{~mL})$ of the stags in this study. These results might indicate that this stag was reproductively active at the time of hunting (ejaculating periodically) since the testes size was above average.

The average sperm concentration of the fluid from the $\mathrm{CE}$ in the present study was $6.1 \times 10^{9} / \mathrm{mL}$ (range $2.7-12.5 \times 10^{9} / \mathrm{mL}$ ), which is approximately twice as dense as the concentration of semen from farmed red deer stags collected during the same reproductive season using an artificial vagina [14,40,41]. This simply implies that, during ejaculation in red deer, the $\mathrm{CE}$ emitted fluid containing the sperm suspension is extended alongside the male genital tract (including secretions of accessory sexual glands) to a $1: 1 \mathrm{v} / \mathrm{v}$ ratio.

Spermatozoa obtained from the CE of red deer stags are reported to show progressive motility even after several hours post-mortem [27-29,41]. The results from the present study confirmed these data, with epididymal spermatozoa still showing progressive motility when evaluated even after $24 \mathrm{~h}$ post-mortem. These viable spermatozoa retrieved post-mortem from the caudae epididymides from wild red deer stags, can be successfully preserved by dilution and freezing. In samples collected from the Mazurian stags $(n=10)$ and kept in vitro at $5^{\circ} \mathrm{C}$, sperm motility (which varied largely among stags initially, from above 10 to $70 \%$ ) reached values $<10 \%$ also with large individual variation, some stags at $44 \mathrm{~h}$ and others not before $90 \mathrm{~h}$ of storage (Gizejewski, unpublished results).

Some of the material in the present study was collected under suboptimal conditions beyond our influence, with a direct address to those stags collected in the Bieszczady mountains, which had the lowest motility compared to $\mathrm{P}$ or $\mathrm{M}$. The rather long interval between death and collection of epididymal contents was caused by the rough terrain where the hunting took place. In addition, the low ambient temperature (approx. +8 to $+14^{\circ} \mathrm{C}$ ) might also have affected the results in the present study, particularly considering specimens collected in the Carpathian mountains, where sperm motility evaluations were not done using a heated block resembling body temperature, which routinely is used for semen evaluation and here it was only used for the Mazurianand Pomeranian-derived material. Therefore, the reliability of the estimated values in this study is influenced by the circumstances under which the evaluations were performed. The fact that the sperm motility was evaluated subjectively might also have influenced the results. Interestingly, however, the results of progressive motility are, at least for stags collected from the M- and P- areas, clearly similar to those reported by Martinez et al. [14] in wild Spanish red deer stags, where progressivity and speed are considered of major relevance for fertility [42]. 
Sperm concentration and morphology evaluation provides a clear view of the normality of the spermatogenesis and its different steps (from spermatocytogenesis to spermiogenesis) as well as of the delicate process of sperm maturation in the epididymis [43]. Despite this obvious value, sperm morphology is rarely evaluated, and few papers have documented sperm morphology in wild red deer [14,41], while more papers have focused on natural, but quasi farmed populations $[42,44,45]$. The evaluation of the sperm morphology showed mean incidences of individual sperm abnormalities below $4 \%$, and the mean incidence for total abnormalities was below $15 \%$ [40]. Compared with other ruminants (e.g. dairy AI bulls) these results would have been considered to be within normal limits [46,47]. However, reference values for sperm morphology in red deer stags are yet to be established. In any case, the results obtained in the present study clearly differ from those reported by Martinez et al. [14] in wild Spanish red deer where a mean of $29 \%$ of abnormal spermatozoa were present. Differences in age, subspecies or methodologies used for registration of morphological deviations might explain the differences. The SEM fine structure confirmed the morphology seen during the evaluation of wet- or stained smears. The defects were similar to what has been described in other ruminant species [48].

\section{Concluding remarks}

Despite that the age/size of animals and their geographical location at hunting clearly influenced testes size and consequently the size/weight of the vesicular glands and sperm motility in caudal spermatozoa, neither sperm numbers nor morphology showed significant differences, and might be used a reference values. However, there is a need to establish comparable reference values for sperm morphology in different subspecies and varieties of red deer [49].

\section{Ethical standards}

The collection and handling of the animal material described in the present manuscript complied with the current laws of the country in which they were performed.

\section{Declaration of interest}

The authors declare that there is no conflict of interest that could be perceived as prejudicing the impartiality of the research reported here.

\section{Funding}

This study was supported by SLU, and funds of the Research Station of the Polish Academy of Sciences at Popielno, Martínez-pastorPoland.

\section{Acknowledgements}

The authors wish to express their gratitude to Karin Selin-Wretling, Annika Rikberg, Marianne Ekwall and of Dr. Hans Ekwall for their excellent technical assistance. The Royal Swedish Academy for Forestry and Agriculture provided Dr. Z. Gizejewski with a visiting scholarship. 


\section{References}

1. International Union for Conservation of Nature, IUCN 2008. 2008 IUCN Red List of Threatened Species. <www.iucnredlist.org>, Downloaded on January 52010.

2. Audigé, L., Wilson, P.R. \& Morris, R.S. 1999. Reproductive performance of farmed red deer (Cervus elaphus) in New Zealand, I. Descriptive data. Anim. Reprod. Sci. 55: 127-141. doi:10.1016/S0378-4320(99)00003-2

3. Berg, D.K., Li, C., Asher, G., Wells, D.N. \& Oback, B. 2007. Red deer cloned from antler stem cells and their differentiated progeny. Biol. Reprod. 77: 384-394.

doi:10.1095/biolreprod.106.058172

4. Haigh, J.C. \& Hudson, R.J. 1993. Farming wapiti and red deer. Mosby, St Louis USA XI.

5. Mitchell, B. 1973. The reproductive performance of wild Scottish red deer, Cervus elaphus. J. Reprod. Fertil. 19(Suppl.): 271-285.

6. Geist, V. 1998. Deer of the World. Stackpole Books, 1st edition.

7. Garde, J.J., Martínez-Pastor, F., Gomendio, M., Malo, A.F., Soler, A.J., Fernández-Santos, M.R., Esteso, M.C., García, A.J., Anel, L. \& Roldán, E.R. 2006. The application of reproductive technologies to natural populations of red deer. Reprod. Domest. Anim. 41 (Suppl. 2): 93-102.

doi:10.1111/j.1439-0531.2006.00773.x

8. Roldan, E.R., Gomendio, M., Garde, J.J., Espeso, G., Ledda, S., Berlinguer, F., del Olmo, A., Soler, A.J., Arregui, L., Crespo, C. \& González, R. 2006. Inbreeding and reproduction in endangered ungulates: preservation of genetic variation through the Organization of Genetic Resource Banks. Reprod. Domest. Anim. 41 (Suppl. 2): 82-92.

doi:10.1111/j.1439-0531.2006.00772.x

9. Bierschwal, C.J., Mather, E.C., Martin, C.E., Murphy, D.A. \& Korschgen, L.J. 1968. Collection of deer semen by electroejaculation. Proc. VI th Int Congr Anim Reprod \& AI, Paris 2: 1001-1004.

10. Jaczewski, Z. \& Morstin, J. 1973. Collection of the semen of the red deer by electroejaculation. Pr. Mater. Zootec. 3: 83-86.

11. Jaczewski, Z. \& Jasiorowski, T. 1974. Observations on the electroejaculation in red deer. Acta ther 19: 151-157.

12. Haigh, J.C. 1984. Artificial insemination of two white-tailed deer. JAVMA 185: 1446-1447.

13. Asher, G.W., Fisher, M.W., Fennessy, P.F., Mackintosh, C.G., Jabbour, H.N. \& Morrow, C.J. 1993. Oestrus synchronization, semen collection and artificial insemination of farmed red deer (Cervus elaphus) and fallow deer (Dama dama). Anim. Reprod. Sci. 33: 241-265. doi:10.1016/0378-4320(93)90118-B

14. Martínez, A.F., Martínez-Pastor, F., Alvarez, M., Fernández-Santos, M.R., Esteso, M.C., de Paz, P., Garde, J.J. \& Anel, L. 2008. Sperm parameters on Iberian red deer: electroejaculation and postmortem collection. Theriogenology 70: 216-226. doi:10.1016/j.theriogenology.2008.04.001

15. Soler, A.J., Pérez-Guzmán, M.D. \& Garde, J.J. 2003. Storage of red deer epididymides for four days at 5 degrees C: effects on sperm motility, viability, and morphological integrity. J. Exp. Zool. A. Comp. Exp. Biol. 295: 188-199.

16. Fernández-Santos, M.R., Esteso, M.C., Montoro, V., Soler, A.J. \& Garde, J.J. 2006. Influence of various permeating cryoprotectants on freezability of Iberian red deer (Cervus elaphus hispanicus) epididymal spermatozoa: effects of concentration and temperature of addition. J. Androl. 27: 734-745. doi:10.2164/jandrol.106.000505

17. Zomborszky, Z., Zubor, T., Toth, J. \& Horn, P. 1999. Sperm collection from shot red deer stags (Cervus elaphus) and the utilisation of sperm frozen and subsequently thawed. Acta Vet. Hung. 47: 263-270. 
18. Zomborszky, Z., Nagy, Sz., Nánássy, L., Szabari, M. \& Bodó, Sz. 2005. Experiences in deer sperm cryopreservation under practical conditions - a pilot study. Anim. Reprod. Sci. 90: 185-190. doi:10.1016/j.anireprosci.2005.01.014

19. Nagy, Sz., Kovács, A., Zubor, T., Zomborszky, Z., Tóth, T. \& Horn, P. 2001. Evaluation of frozen/ thawed deer spermatozoa: short communication. Acta Vet. Hung. 49: 223-227.

doi:10.1556/AVet.49.2001.2.12

20. Soler, A.J., Esteso, M.C., Fernández-Santos, M.R. \& Garde, J.J. 2005. Characteristics of Iberian red deer (Cervus elaphus hispanicus) spermatozoa cryopreserved after storage at 5 degrees $\mathrm{C}$ in the epididymis for several days. Theriogenology 64: 1503-1517.

doi:10.1016/j.theriogenology.2005.03.013

21. Fernández-Santos, M.R., Esteso, M.C., Montoro, V., Soler, A.J. \& Garde, J.J. 2006. Cryopreservation of Iberian red deer (Cervus elaphus hispanicus) epididymal spermatozoa: effects of egg yolk, glycerol and cooling rate. Theriogenology 66: 1931-1942.

doi:10.1016/j.theriogenology.2006.05.012

22. Fernández-Santos, M.R., Esteso, M.C., Soler, A.J., Montoro, V. \& Garde, J.J. 2006. Effects of egg yolk and cooling rate on the survival of refrigerated red deer (Cervus elaphus hispanicus) epididymal spermatozoa. Reprod. Domest. Anim. 41: 114-118.

doi:10.1111/j.1439-0531.2006.00649.x

23. Martínez-Pastor, F., Martínez, F., Alvarez, M., Maroto-Morales, A., García-Alvarez, O., Soler, A.J., Garde, J.J., de Paz, P. \& Anel, L. 2009. Cryopreservation of Iberian red deer (Cervus elaphus hispanicus) spermatozoa obtained by electroejaculation. Theriogenology 71: 628-638. doi:10.1016/j.theriogenology.2008.09.033

24. Krzywinski, A. 1976. Collection of red deer semen with the artificial vagina. Proc. VIII Int Congr Anim Reprod \& AI, Krakow, 4: 1002-1005.

25. Krzywinski, A. \& Jaczewski, Z. 1978. Observations on the artificial breeding of red deer. Proc. Symp. Zool. Soc. London 43: 271-287.

26. Gizejewski, Z. 1996. Modification of artificial vagina allowing to separate semen fractions and to observe some ejaculations details in red deer/Cervus elaphus/. J. Physiol. Pharmacol. 47: 150.

27. Krzywinski, A. 1981. Freezing of post mortem collected semen from moose and red deer. Acta theriol. 26: 424-426.

28. Miles, P.D.N., Sympson, P. \& Allende, R.A. 1992. Post-mortem recovery of semen from red deer (Cervus elaphus Linnaeus) and its cryopreservation in liquid nitrogen. Rev. Arg. Prod. Anim. 12: 57-64.

29. Fernández-Santos, M.R., Domínguez-Rebolledo, A.E., Esteso, M.C., Garde, J.J. \& Martínez-Pastor, F. 2009. Refrigerated storage of red deer epididymal spermatozoa in the epididymis, diluted and with vitamin C supplementation. Reprod. Domest. Anim. 44: 212-20. doi:10.1111/j.1439-0531.2007.01032.x

30. Fernández-Santos, M.R., Martínez-Pastor, F., Matias, D., Domínguez-Rebolledo, A.E., Esteso, M.C., Montoro, V. \& Garde, J.J. 2009. Effects of long-term chilled storage of red deer epididymides on DNA integrity and motility of thawed spermatozoa. Anim Reprod Sci 111: 93-104. doi:10.1016/j.anireprosci.2008.02.001

31. Górski, T., Demidowicz, G., Deputat, T., Górska, K., Marcinkowska, I., Spoz-Pać, W., Zaliwski, A. \& Wróblewska, E. 1998. Total Precipitation for a Vegetation Period. Numerical map. IUNG Puławy, Poland.

32. Raesfeld, Fv. \& Reulecke, K. 1998. Das Rotwild. Paul Parey Verlag Hamburg und Berlin, pp 63-68.

33. Hancock, J.L. 1957. The morphology of boar spermatozoa. J. Royal. Microsc. Soc. 76: 84-97.

34. Williams, W. \& Utica, N. 1920. Technique of collecting semen for laboratory examination with a review of several diseased bulls. Cornell Vet. 10: 87-94. 
35. Lagerlöf, N. 1934. Morphologische Undersuchungen über Veränderungen im Spermabild und in den Hoden bei Bullen mit verminderte oder aufgehobener Fertilität. [Morphological studies of changes in sperm morphology and in the testes of bulls with lowered or no fertility]. Acta. Pathol. Microbiol. Scand., Suppl. 19.

36. Malo, A.F., Garde, J.J., Soler, A.J., García, A.J., Gomendio, M. \& Roldan, E.R. 2005. Male fertility in natural populations of red deer is determined by sperm velocity and the proportion of normal spermatozoa. Biol. Reprod. 72: 822-829. doi:10.1095/biolreprod.104.036368

37. Lunstra, D.D., Wise, T.H. \& Ford, J.J. 2003. Sertoli cells in the boar testis: changes during development and compensatory hypertrophy after hemicastration at different ages. Biol. Reprod. 68: 140-150. doi:10.1095/biolreprod.102.006510

38. Rörig, A. 1889. Welche Beziehungen bestehen zwischen den Reproduktionsorganen der Cerviden und der Geweihbildung derselben? Arch. f. Entwickl. Mech. d. Org. 8: 382-447.

39. Malo, A.F., Roldan, E.R., Garde, J.J., Soler, A.J., Vicente, J., Gortazar, C. \& Gomendio, M. 2009. What does testosterone do for red deer males? Proc. Biol. Sci. 276: 971-980. doi:10.1098/rspb.2008.1367

40. Gizejewski, Z. 2004 Effect of season on characteristics of red deer/Cervus elaphus L./ semen collected using modified artificial vagina. Reprod. Biol. 4: 51-66.

41. Garde, J.J., Ortiz, N., García, A.J., Gallego, L., Landete-Castillejos, T. \& López, A. 1998. Postmortem assessment of sperm characteristics of the red deer during the breeding season. Arch. Androl. 41: 195202. doi: $10.3109 / 01485019808994891$

42. Fernández-Santos, M.R, Martínez-Pastor, F., García-Macías, V., Esteso, M.C., Soler, A.J., Paz, P., Anel, L. \& Garde, J.J. 2007. Sperm characteristics and DNA integrity of Iberian red deer (Cervus elaphus hispanicus) epididymal spermatozoa frozen in the presence of enzymatic and nonenzymatic antioxidants. J. Androl. 28: 294-305. doi:10.2164/jandrol.106.000935

43. Malo, A.F., Roldan, E.R., Garde, J., Soler, A.J. \& Gomendio, M. 2005. Antlers honestly advertise sperm production and quality. Proc. Biol. Sci. 272: 149-157. doi:10.1098/rspb.2004.2933

44. Esteso, M.C., Soler, A.J., Fernández-Santos, M.R., Quintero-Moreno, A.A. \& Garde, J.J. 2006. Functional significance of the sperm head morphometric size and shape for determining freezability in iberian red deer (Cervus elaphus hispanicus) epididymal sperm samples. J. Androl. 27: 662-670. doi:10.2164/jandrol.106.000489

45. Esteso, M.C., Fernández-Santos, M.R., Soler, A.J., Montoro, V., Martínez-Pastor, F. \& Garde, J.J. 2009. Identification of sperm-head morphometric subpopulations in iberian red deer epididymal sperm samples. Reprod. Domest. Anim. 44: 206-211. doi:10.1111/j.1439-0531.2007.01029.x

46. Söderquist, L., Janson, L., Larsson, K. \& Einarsson, S. 1991. Sperm morphology and fertility in A.I bulls. J. Vet. Med. Series A 38: 534-543. doi:10.1111/j.1439-0442.1991.tb01045.x

47. Rodriguez-Martinez, H. \& Barth, A.D. 2007. In vitro evaluation of sperm quality related to in vivo function and fertility. In: Juengel, J.I., Murray, J.F. \& Smith, M.F. (eds.). Reproduction in Domestic Ruminants VI. Nottingham University Press, Nottingham, UK, pp 39-54.

48. Barth, A.D. \& Oko, R.J. 1989. Defects of the sperm head In Abnormal morphology of bovine spermatozoa. Iowa State University Press, Ames IA.

49. Whitehead, G.K. 1972. Deer of the World. Constable and Co., London. 